\title{
Liver disease in patients with joint symptoms
}

\author{
ANGELA M. HILTON, B. E. BOYES, PATRICIA J. SMITH, J. SHARP, AND I. W. DYMOCK \\ From the Departments of Medicine and Rheumatology, University Hospital of South Manchester, Withington \\ Hospital, West Didsbury, Manchester
}

It is well established that hepatic abnormalities may occur in patients with rheumatoid arthritis (RA) and other connective tissue disorders and these changes have usually been attributed to the systemic nature of the underlying disease process. Abnormalities reported include minor derangements of liver function (Movitt and Davis, 1953) and other abnormalities which have been related to the severity of the associated rheumatoid disease (Lef kovits and Farrow, 1955; Kendall, Cockel, Becker, and Hawkins, 1970). Indices of hepatic derangement have included raised alkaline phosphatase/5-nucleotidase levels (Kendall and others, 1970; Kendall, Farr, Bold, and Hawkins, 1971; Cockel, Kendall, Becker, and Hawkins, 1971) and the detection of mitochondrial antibodies (Walker, Doniach, and Doniach, 1970; Whaley, Goudie, Williamson, Nuki, Dick, and Buchanan, 1970).

Histological changes have been noted, such as infiltration of the portal tracts by chronic inflammatory cells (Lefkovits and Farrow, 1955; Schaller, Beckwith, and Wedgwood, 1970) and fatty change (Movitt and Davis, 1953). In juvenile rheumatoid arthritis, hepatomegaly and derangement of liver function is well documented and hepatic histology has shown nonspecific infiltration of inflammatory cells in the portal tracts and hyperplasia of Kupffer cells (Schaller and others, 1970; Kornreich, Malouf, and Hanson, 1971). Walker and others (1970), in a study of thirty-five hospital patients found on screening to have mitochondrial antibodies, identified ten patients with subclinical liver disease. Of these ten patients, nine had rheumatological disorders (including two patients with RA, two with systemic lupus erythematosus, three with polyarthralgia, and one each with polymyalgia rheumatica and osteoarthrosis). Eight of these ten patients had liver biopsies which showed hepatitis of varying degree.

We report a group of thirty patients, who presented at a rheumatology clinic with symptoms relating to the locomotor system and who were found on routine clinical examination or biochemical screening to have hepatomegaly and/or abnormal routine liver function tests. Detailed hepatic investigations were performed in these patients to determine the cause and significance of these findings.

\section{Patients and methods}

Thirty patients who presented to a rheumatology clinic over a 2-year period were included in the study. The rheumatological diagnoses are summarized in Table I. A biochemical profile, which includes estimations of serum albumin, globulin, alkaline phosphatase, bilirubin, and aminotransferase (SGOT), is obtained in all newpatients attending the clinic. In fourteen the clinical of biochemical evidence of liver disease was noted at their first visit, while in the remainder it was detected when they attended for review of their rheumatic disease. In the latter patients a biochemical profile is requested only if indicated on clinical grounds and therefore liver disease in review patients with biochemical abnormalities alone was probably undetected. Twenty patients were referred for further investigation because of the presence of both hepatomegaly and abnormal liver function tests, five because of hepatomegaly with normal liver function tests, and five because of abnormal liver function tests without hepatomegaly. In addition to the routine liver function tests listed above, 5-nucleotidase levels were estimated when indicated and the patients were screened for hepatitis B antigen (HBAg) and mitochondrial and smooth muscle antibodies. Twenty-three patients had a bromsulphalein retention test $(5 \mathrm{mg} / \mathrm{kg}$ i.v. with $10 \mathrm{ml}$ blood samples at 25 and 45 mins after injection of dye). A liver biopsy was obtained in twenty-one patients.

Table I Rheumatological diagnoses in thirty patients

Inflammatory polyarthritis

Seropositive

Seronegative

Systemic lupus erythematosus

Polyarthralgia

Generalized osteoarthrosis

Gout

Psoriatic arthropathy

Giant cell arteritis 


\section{Results}

Table II summarizes the clinical data and results of hepatic investigations in the thirty patients.

\section{ROUTINE LIVER FUNCTION TESTS}

Twenty-five patients had abnormalities of routine liver function tests. The commonest disturbances were raised aminotransferases (19 patients) and raised alkaline phosphatase/5-nucleotidase levels (22 patients). In eleven patients a raised alkaline phosphatase and 5-nucleotidase were the sole abnormalities of routine liver function tests. Six patients had a low serum albumin $(<3.0 \mathrm{~g} / 100 \mathrm{ml})$ and sixteen patients raised serum globulin $(>3.5 \mathrm{~g} / 100$ $\mathrm{ml})$. In two the serum bilirubin was raised.

\section{BROMSULPHALEIN RETENTION TESTS}

Abnormal BSP retention occurred in eighteen of the twenty-three patients tested (in excess of 7\% at 45 mins). The range of abnormality was from 9 to $50 \%$ BSP retention.

\section{LIVER IMMUNOLOGY}

Mitochondrial antibodies alone were detected in two patients and smooth muscle antibody alone in one patient. Another patient had both antibodies. One patient was HBAg positive.

\section{LIVER HISTOLOGY}

Twenty-one liver biopsies were obtained and eighteen were abnormal, providing a definite hepatic diagnosis in fourteen patients. The final hepatic diagnoses are listed in Table III. A wide spectrum of liver disease has been revealed and a definite hepatic diagnosis reached in twenty patients.

\section{ALCOHOLIC LIVER DISEASE}

Alcoholic liver disease occurred in three patients (Cases 13, 17, and 19) and was associated with hyperlipidaemia and hyperuricaemia in each patient. The rheumatological disorders were generalized osteoarthrosis, gout, and a nonspecific polyarthralgia. A liver biopsy was performed on one of these patients and showed severe fatty change.

\section{PRIMARY BILIARY CIRRHOSIS}

Three patients had primary biliary cirrhosis. In two patients this was associated with a seronegative inflammatory polyarthritis (Cases 24 and 30) and with seropositive rheumatoid arthritis in the other. The latter (Case 22) was a 42-year-old lady who had had seropositive RA since adolescence. Clinical examination showed no stigmata of chronic liver disease and no hepatomegaly, but investigations revealed a markedly raised alkaline phosphatase and 5-nucleotidase, raised aminotransferases, abnormal BSP retention, and positive mitochondrial antibodies.
Liver biopsy showed infiltration of the portal tracts with lymphocytes and plasma cells and a few bile duct granulomata. A diagnosis of early primary biliary cirrhosis was made. This patient has an elder brother who is known to have primary biliary cirrhosis but no joint disease.

\section{DRUG-INDUCED LIVER DISEASE}

Three patients had a transient disturbance of hepatic function consisting of hepatomegaly and a rise in aminotransferases which coincided with drug therapy. In two of these patients abnormal BSP retention occurred in addition to the above abnormalities. The drug responsible for the hepatic damage in these two patients was thought to be indomethacin (Cases 8 and 11). The other patient had raised alkaline phosphatase with 5-nucleotidase in addition to raised aminotransferases and hepatomegaly which occurred in relation to azathioprine therapy for giant cell arteritis (Case 29). In all three patients withdrawal of these drugs was followed by rapid resolution of the biochemical abnormalities, and in the two patients with indomethacin toxicity the liver size returned to normal.

\section{CHRONIC PERSISTENT HEPATITIS}

Three patients had chronic persistent hepatitis, of whom two had systemic lupus erythematosus (Cases 26 and 28). The other patient (Case 14), a 51-yearold woman, presented with a nonspecific arthralgia. Examination showed hepatomegaly and multiple spider naevi, and further investigation showed abnormal BSP retention, a positive $\mathrm{HBAg}$ test, and liver biopsy confirmed a chronic persistent hepatitis. She has received no therapy and on follow-up for 2 years has remained repeatedly $\mathrm{HBAg}$ positive with no evidence of clinical or histological progression of the disease.

\section{CHRONIC ACTIVE HEPATITIS}

Two patients had chronic active hepatitis, confirmed by liver biopsy. Both were HBAg negative. One (Case 5) had a nonspecific polyarthralgia as a presenting symptom and routine clinical examination revealed hepatomegaly. Prednisolone therapy induced diabetes mellitus but subsequently azathioprine and prednisolone in low dosage has maintained satisfactory control of his hepatic disease. The other patient (Case 25) had a 4-year history of seropositive rheumatoid arthritis and was found to have hepatomegaly. Biochemical abnormalities included a high serum globulin $\left(4.9 \mathrm{~g} / 100 \mathrm{ml}\right.$, raised $\alpha_{2}$ - and $\gamma$-globulin on electrophoresis), raised alkaline phosphatase, 5-nucleotidase, and SGOT, and prothrombin activity $65 \%$. BSP retention was within normal limits but a liver biopsy showed chronic aggressive hepatitis with regeneration nodules and portal tract fibrosis. After prednisolone and azathioprine therapy the liver function tests have returned to normal. 
Table II Clinical data and results of hepatic investigations

\begin{tabular}{|c|c|c|c|c|c|c|c|c|c|}
\hline \multirow[b]{2}{*}{ Case no. } & \multirow[b]{2}{*}{ Sex } & \multirow[b]{2}{*}{$\begin{array}{c}\text { Age } \\
\text { (yrs) }\end{array}$} & \multirow[b]{2}{*}{ Hepatomegaly } & \multicolumn{4}{|c|}{ Liver function } & \multirow[b]{2}{*}{$\begin{array}{l}\text { Bromsulpha- } \\
\text { lein } \\
\text { retention (\% } \\
\text { at } 45 \text { mins) }\end{array}$} & \multirow[b]{2}{*}{$\begin{array}{l}\text { Hepatitis } B \\
\text { antigen }\end{array}$} \\
\hline & & & & $\begin{array}{l}\text { Bilirubin } \\
(N 0 \cdot 2-0.9 \\
m g / 100 \mathrm{ml})\end{array}$ & $\begin{array}{l}\text { Alkaline } \\
\text { phosphatase } \\
\text { (3-13 K-A } \\
\text { units) }\end{array}$ & $\begin{array}{l}\text { 5-Nucleotidase } \\
(3 \cdot 5-11 \cdot 0 \\
\mathrm{mIU} / \mathrm{ml})\end{array}$ & $\begin{array}{l}\text { SGOT } \\
\text { (7-46 } \\
\text { K units) }\end{array}$ & & \\
\hline 1 & $\mathbf{F}$ & 64 & + & 0.3 & 11 & - & 58 & 18 & - \\
\hline 2 & $\mathbf{M}$ & 44 & + & 0.5 & 10 & - & 7 & Normal & - \\
\hline 3 & $\mathbf{M}$ & 46 & + & 0.4 & 20 & - & 63 & 16 & - \\
\hline 4 & $\mathbf{F}$ & 62 & - & 0.3 & 26 & $19 \cdot 2$ & 84 & 44 & - \\
\hline $\begin{array}{l}5 \\
6 \\
7 \\
8\end{array}$ & $\begin{array}{l}\mathbf{M} \\
\mathbf{F} \\
\mathbf{M} \\
\mathbf{F}\end{array}$ & $\begin{array}{l}48 \\
65 \\
66 \\
49\end{array}$ & $\begin{array}{l}+ \\
+ \\
+ \\
+\end{array}$ & $\begin{array}{l}0.4 \\
0.4 \\
0.2 \\
0.2\end{array}$ & $\begin{array}{r}7 \\
15 \\
31 \\
14\end{array}$ & $\begin{array}{c}- \\
14 \\
52 \\
7 \cdot 2\end{array}$ & $\begin{array}{r}169 \\
19 \\
5 \\
120\end{array}$ & $\begin{array}{l}33 \\
\frac{1}{24} \cdot 5\end{array}$ & $\begin{array}{l}\bar{z} \\
\bar{z}\end{array}$ \\
\hline $\begin{array}{r}9 \\
10 \\
11\end{array}$ & $\begin{array}{l}\mathbf{F} \\
\mathbf{M} \\
\mathbf{M}\end{array}$ & $\begin{array}{l}69 \\
45 \\
52\end{array}$ & $\begin{array}{l}+ \\
+ \\
+\end{array}$ & $\begin{array}{l}0.3 \\
0 \cdot 4 \\
0 \cdot 2\end{array}$ & $\begin{array}{r}15 \\
74 \\
7\end{array}$ & $\begin{array}{l}21 \cdot 3 \\
23 \\
-\end{array}$ & $\begin{array}{r}18 \\
9 \\
59\end{array}$ & $\begin{array}{l}17 \\
10 \\
10\end{array}$ & $\begin{array}{l}- \\
\overline{-}\end{array}$ \\
\hline $\begin{array}{l}12 \\
13 \\
14\end{array}$ & $\begin{array}{l}\mathbf{F} \\
\mathbf{M} \\
\mathbf{F}\end{array}$ & $\begin{array}{l}54 \\
50 \\
51\end{array}$ & $\begin{array}{l}+ \\
+ \\
+\end{array}$ & $\begin{array}{l}0.3 \\
0.5 \\
0.8\end{array}$ & $\begin{array}{l}30 \\
17 \\
16\end{array}$ & $\begin{array}{c}3 \cdot 1 \\
11 \cdot 8 \\
6\end{array}$ & $\begin{array}{l}20 \\
37 \\
50\end{array}$ & $\overline{-}$ & $\begin{array}{l}- \\
\text { Positive }\end{array}$ \\
\hline 15 & $\mathbf{M}$ & 45 & - & 0.3 & 23 & 16.5 & 19 & 13 & - \\
\hline 16 & $\mathbf{F}$ & 36 & + & 2.7 & 11 & - & 120 & - & - \\
\hline $\begin{array}{l}17 \\
18 \\
19 \\
20 \\
21\end{array}$ & $\begin{array}{l}\mathbf{F} \\
\mathbf{F} \\
\mathbf{M} \\
\mathbf{M} \\
\mathbf{F}\end{array}$ & $\begin{array}{l}49 \\
34 \\
38 \\
67 \\
64\end{array}$ & $\begin{array}{l}+ \\
+ \\
+ \\
+ \\
+\end{array}$ & $\begin{array}{l}0.8 \\
0.3 \\
0.3 \\
0.2 \\
0.4\end{array}$ & $\begin{array}{r}13 \\
10 \\
7 \\
20 \\
32\end{array}$ & $\begin{array}{c}1 \cdot 1 \\
9.6 \\
3 \cdot 7 \\
2 \\
24 \cdot 1\end{array}$ & $\begin{array}{r}120 \\
64 \\
65 \\
10 \\
47\end{array}$ & $\begin{array}{r}30 \\
12 \\
-3 \\
11\end{array}$ & $\begin{array}{l}- \\
\overline{-} \\
\overline{-}\end{array}$ \\
\hline 22 & $\mathbf{F}$ & 42 & - & 1.0 & 140 & 165 & 199 & 28 & - \\
\hline $\begin{array}{l}23 \\
24\end{array}$ & $\begin{array}{l}\mathbf{M} \\
\mathbf{F}\end{array}$ & $\begin{array}{l}25 \\
51\end{array}$ & $\overline{+}$ & $\begin{array}{l}0.5 \\
0 \cdot 4\end{array}$ & $\begin{array}{l}24 \\
48\end{array}$ & $\begin{array}{l}32 \cdot 5 \\
47 \cdot 8\end{array}$ & $\begin{array}{l}55 \\
24\end{array}$ & $\overline{7}$ & $\overline{-}$ \\
\hline 25 & $\mathbf{F}$ & 45 & + & 0.4 & 29 & 67 & 48 & 5 & \\
\hline $\begin{array}{l}26 \\
27\end{array}$ & $\begin{array}{l}\mathbf{F} \\
\mathbf{M}\end{array}$ & $\begin{array}{l}34 \\
68\end{array}$ & $\overline{+}$ & $\begin{array}{l}0 \cdot 2 \\
0 \cdot 4\end{array}$ & $\begin{array}{l}24 \\
27\end{array}$ & $\begin{array}{l}16 \cdot 3 \\
20 \cdot 6\end{array}$ & $\begin{array}{l}51 \\
20\end{array}$ & $\begin{array}{r}8 \\
29\end{array}$ & $\overline{-}$ \\
\hline $\begin{array}{l}28 \\
29\end{array}$ & $\begin{array}{l}\mathbf{F} \\
\mathbf{F}\end{array}$ & $\begin{array}{l}62 \\
70\end{array}$ & + & $\begin{array}{l}0.3 \\
0.9\end{array}$ & $\begin{array}{r}47 \\
104\end{array}$ & $\begin{array}{l}76 \\
-\end{array}$ & $\begin{array}{r}74 \\
330\end{array}$ & $\begin{array}{l}\text { Normal } \\
-\end{array}$ & $\overline{-}$ \\
\hline 30 & $\mathbf{F}$ & 51 & + & $8 \cdot 8$ & 50 & 157.5 & 272 & 50 & - \\
\hline
\end{tabular}

\section{HEPATIC SIDEROSIS}

Two patients (Cases 6 and 21) were found to have increased iron deposition on histological examination which was attributed to prolonged iron therapy.

\section{Miscellaneous diagnoses}

Case 3 A Jamaican man, aged 46 years, was found to have sarcoidosis (Fig. 1). He presented with a polyarthralgia which resolved within a few weeks. The sole abnormality on examination was hepatomegaly; routine liver function tests showed a raised SGOT and he had abnormal BSP retention. The liver biopsy showed multiple granulomatous lesions scattered throughout the liver parenchyma. At that time the chest $x$-ray was reported as normal.
Eighteen months later the chest $x$-ray showed the typical appearances of sarcoidosis with bilateral hilar adenopathy and pulmonary infiltration. The Kveim test was positive.

Case 4 Another patient of particular interest was a 62-year-old woman who had had seropositive rheumatoid arthritis for over 20 years. In 1967, Felty's syndrome was diagnosed when a profound neutropenia was found associated with splenomegaly. Because of repeated infections, splenectomy was performed in November 1971 which resulted in clinical and haematological improvement. Liver biopsy at the time of operation, before which she had raised aminotransferases and abnormal BSP retention, showed an active arteritis with round cell 


\begin{tabular}{|c|c|c|c|c|}
\hline $\begin{array}{l}\text { Mitochondrial } \\
\text { antibody }\end{array}$ & $\begin{array}{l}\text { Smooth } \\
\text { muscle } \\
\text { antibody }\end{array}$ & Liver biopsy & Rheumatological diagnosis & Hepatic diagnosis \\
\hline- & - & $\begin{array}{l}\text { Slight increase in lymphocytes in portal } \\
\text { tracts }\end{array}$ & SLE & No diagnosis \\
\hline - & - & $\begin{array}{l}\text { Mild fatty change, slight increase in lym- } \\
\text { phocytes in portal tracts }\end{array}$ & Inflammatory polyarthritis (sero-ve) & No diagnosis \\
\hline- & - & $\begin{array}{l}\text { Granulomatous lesions throughout liver } \\
\text { parenchyma }\end{array}$ & Sarcoidosis & Sarcoidosis \\
\hline- & - & $\begin{array}{l}\text { Arteritis; lymphocytic infiltration of } \\
\text { portal tracts }\end{array}$ & RA (sero + ve) + Felty's syndrome & Polyarteritis nodosa \\
\hline - & - & Chronic aggressive hepatitis & Nonspecific polyarthralgia & Chronic active hepatitis \\
\hline - & - & Increased iron deposition & RA (sero + ve) & Hepatic siderosis \\
\hline - & - & Not done & RA (sero + ve) & No diagnosis \\
\hline- & - & Not done & RA (sero+ve) & $\begin{array}{l}\text { Drug toxicity } \\
\text { (indomethacin) }\end{array}$ \\
\hline- & - & Severe fatty change & Inflammatory polyarthritis (sero-ve) & Fatty liver \\
\hline - & - & Biopsy refused & RA (sero + ve) & No diagnosis \\
\hline- & $\begin{array}{l}\text { Positive } \\
1 / 16\end{array}$ & Normal & RA (sero + ve) & $\begin{array}{l}\text { Drug toxicity } \\
\text { (indomethacin) }\end{array}$ \\
\hline - & - & Not done & SLE & No diagnosis \\
\hline - & - & Not done & Nonspecific polyarthralgia & Alcoholic liver disease \\
\hline- & - & Chronic persistent hepatitis & Nonspecific polyarthralgia & $\begin{array}{l}\text { Chronic persistent } \\
\text { hepatitis }\end{array}$ \\
\hline- & - & $\begin{array}{l}\text { Nonspecific lymphocytic infiltration of } \\
\text { portal tracts }\end{array}$ & Inflammatory polyarthritis (sero-ve) & No diagnosis \\
\hline- & - & $\begin{array}{l}\text { Cardiac cirrhosis, centrilobular necrosis, } \\
\text { 'nutmeg liver' }\end{array}$ & RA (sero+ve) & Cardiac cirrhosis \\
\hline- & $\overline{-}$ & $\begin{array}{l}\text { Severe fatty change } \\
\text { Not done }\end{array}$ & $\begin{array}{l}\text { Generalized osteoarthrosis } \\
\text { RA (sero+ve) }\end{array}$ & $\begin{array}{l}\text { Alcoholic liver disease } \\
\text { No diagnosis }\end{array}$ \\
\hline- & - & Not done & Gout & Alcoholic liver disease \\
\hline- & - & Normal & SLE & No diagnosis \\
\hline- & - & $\begin{array}{l}\text { Increased iron deposition, increase in } \\
\text { lymphocytes, plasma cells, in portal } \\
\text { tracts }\end{array}$ & Psoriatic arthropathy & Hepatic siderosis \\
\hline Positive $1 / 16$ & - & $\begin{array}{l}\text { Plasma cells and lymphocytes infiltrating } \\
\text { portal tracts-no fibrosis, granulomata } \\
\text { (early primary biliary cirrhosis) }\end{array}$ & RA (sero+ve) & Primary biliary cirrhosis \\
\hline- & - & Not done & Inflammatory polyarthritis (sero-ve) & No diagnosis \\
\hline Positive $1 / 4$ & $\begin{array}{l}\text { Positive } \\
1 / 16\end{array}$ & Or a & Inflammatory polyarthritis (sero-ve) & $\begin{array}{l}\text { Early primary biliary } \\
\text { cirrhosis }\end{array}$ \\
\hline- & - & $\begin{array}{l}\text { Chronic aggressive hepatitis with } \\
\text { regeneration nodules and portal tract } \\
\text { fibrosis }\end{array}$ & RA (sero+ve) & Chronic active hepatitis \\
\hline- & - & Chronic persistent hepatitis & SLE & Chronic persistent hepatitis \\
\hline- & - & $\begin{array}{l}\text { Small foci or polymorphs in lobules and } \\
\text { sinusoids; otherwise normal }\end{array}$ & $\mathbf{R A}($ sero + ve) & No diagnosis \\
\hline- & - & Chronic persistent hepatitis & SLE & Chronic persistent hepatitis \\
\hline - & - & Not done & Giant cell arteritis & $\begin{array}{l}\text { Azathioprine hepato- } \\
\text { toxicity }\end{array}$ \\
\hline Positive $1 / 16$ & - & Primary biliary cirrhosis & Inflammatory polyarthritis (sero-ve) & Primary biliary cirrhosis \\
\hline
\end{tabular}

Table III Hepatic diagnoses in thirty patients studied

Alcoholic liver disease

Drug-induced liver disorder

Primary biliary cirrhosis

Chronic persistent hepatitis

Chronic active hepatitis

Hepatic siderosis

Polyarteritis nodosa

Sarcoidosis

Severe fatty change

Cardiac cirrhosis

No definite diagnosis

infiltration and fibrinoid necrosis in the walls of hepatic vessels. In addition there was diffuse infiltration of lymphocytes in the portal tracts (Fig. 2). These appearances were considered to be consistent with a diagnosis of polyarteritis nodosa.

One patient with a seronegative polyarthritis was found to have severe fatty change (Case 9), and another patient with seropositive RA had disturbances of hepatic function and hepatomegaly due to cardiac cirrhosis, secondary to mitral valve disease (Case 16).

In ten patients no definite hepatic diagnosis was reached to explain the hepatic abnormalities. In this group five patients had had liver biopsies. One of these biopsies was normal and the others showed minor nonspecific changes including slight lymphocytic infiltration of the portal tracts ( 3 biopsies), fatty change (1 biopsy), and small foci of polymorphs in 


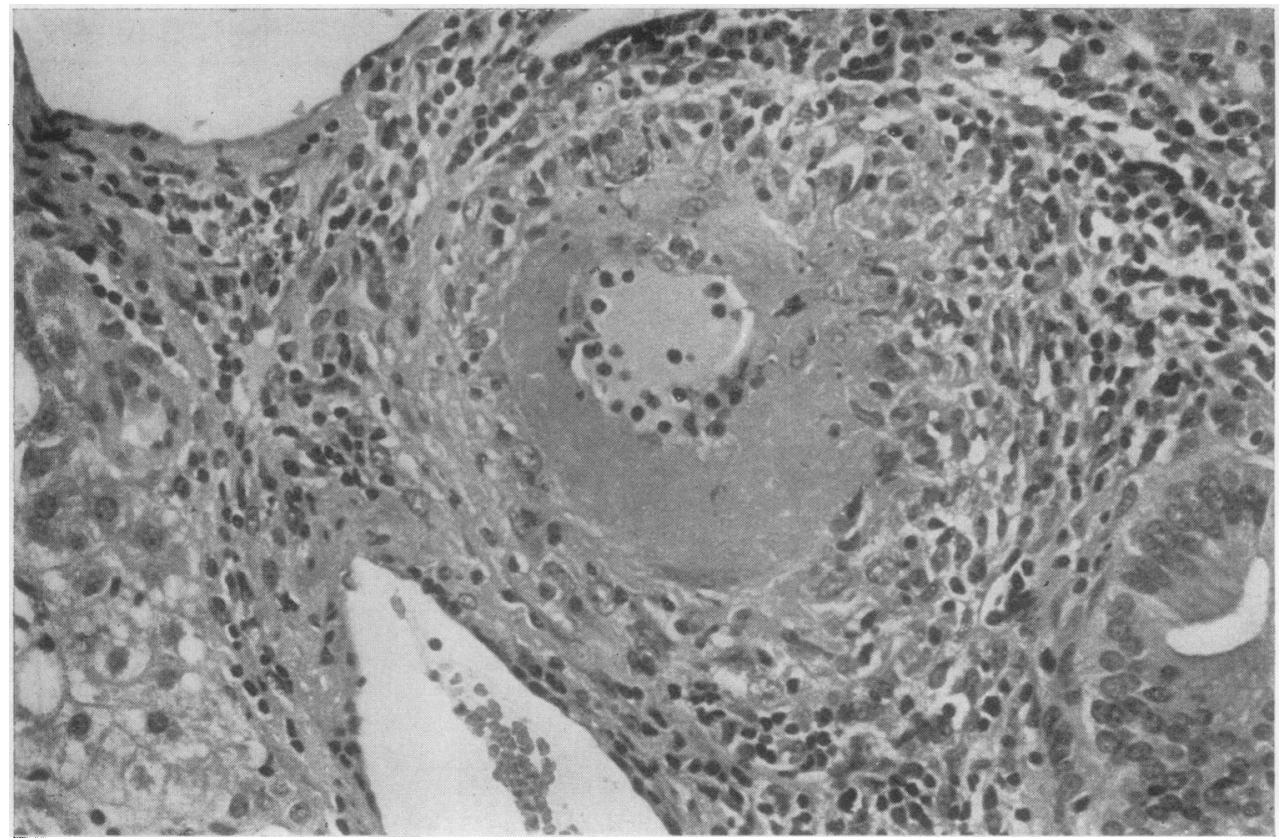

FIG. 1 Liver biopsy from Case 3 illustrating one of the granulomata found in the biopsy specimen. This patient was ultimately proven to have sarcoidosis. $\times 10$

lobules and sinusoids (1 biopsy). Eight of these patients had hepatomegaly, seven had a raised alkaline phosphatase/5-nucleotidase, three had raised aminotransferases, and six had abnormal BSP retention.

\section{Discussion}

The detailed investigation of these thirty patients has revealed varied hepatic pathology. In twenty of them a definitive diagnosis, not previously suspected, was reached. Three patients were shown to have disturbances of liver function attributable to drug therapy (indomethacin or azathioprine) which resolved when the drugs were withdrawn, illustrating the importance of drug toxicity as a cause of liver abnormalities in patients with rheumatological disorders. Many of the drugs used in the treatment of rheumatoid arthritis and related conditions are potentially hepatotoxic. Salicylate therapy has been shown to cause raised serum transaminases (Russell, Sturge, and Smith, 1971; Rich and Johnson, 1973). These authors found that the abnormalities were dose related and reduction of salicylate dosage led to a fall in transaminases. Two of the six patients described by Rich and Johnson had liver biopsies which showed round cell infiltration of the portal tracts in both and single cell necrosis in the parenchyma in one. Some of our patients in whom no diagnosis was reached had similar histological changes to these. Toxic hepatitis has also been described in association with indo- methacin (Fenech, Bannister, and Grech, 1967; Kelsey and Scharyj, 1967), phenylbutazone (Engleman, Krupp, Rinehart, Jones, and Gibson, 1954; Schenker, Olson, Dunn, Breen, and Combes, 1973), gold (Schenker and others, 1973), and azathioprine (Meyler and Herxheimer, 1972). Drug toxicity may have been a contributory factor in some of the ten patients in whom no other cause could be found for their hepatic dysfunction.

Polyarteritis nodosa was diagnosed on the liver biopsy of the patient with Felty's syndrome who also had lymphocytic infiltration of the portal tracts. Blendis, Ansell, Jones, Hamilton, and Williams (1970) studied liver function and histology in twelve patients with Felty's syndrome and showed that lymphocytic infiltration of the portal tracts and sinusoids was the predominant histological abnormality. It is uncertain whether these findings are specific to Felty's syndrome or are merely part of the rheumatoid process. The detection of polyarteritis nodosa in our patient was unexpected, although the association of polyarteritis nodosa with seropositive rheumatoid arthritis has long been recognized (Ball, 1954). An association between polyarteritis nodosa and the hepatitis $B$ antigen has also been reported (Gocke, Hsu, Morgan, Bombardieri, Lockshin, and Christian, 1970), but this antigen was not detected in our patient.

MacKay, Taft, and Cowling (1959) have described hepatic abnormalities in systemic lupus erythematosus. They studied nineteen patients, noting 


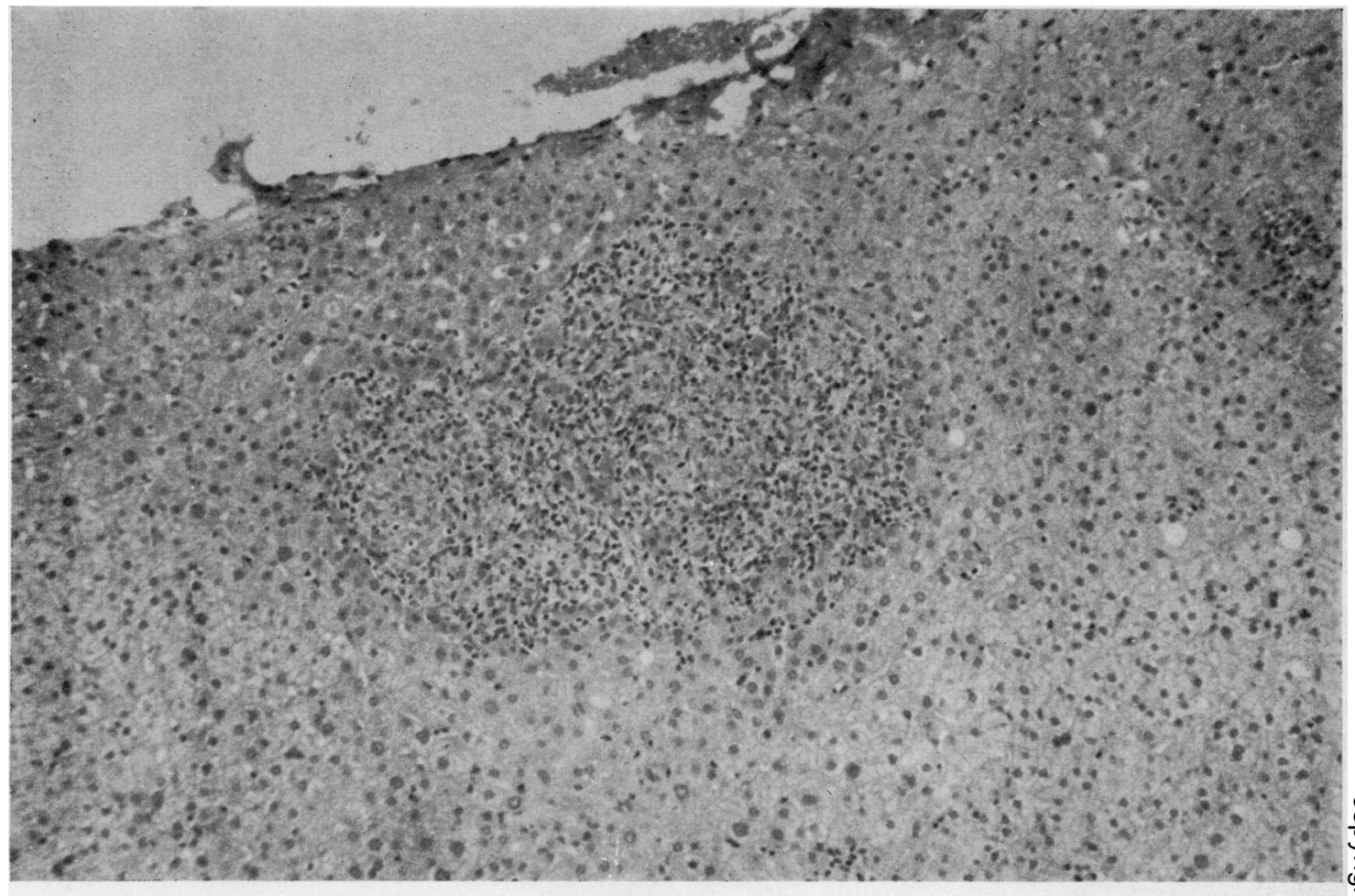

(a)

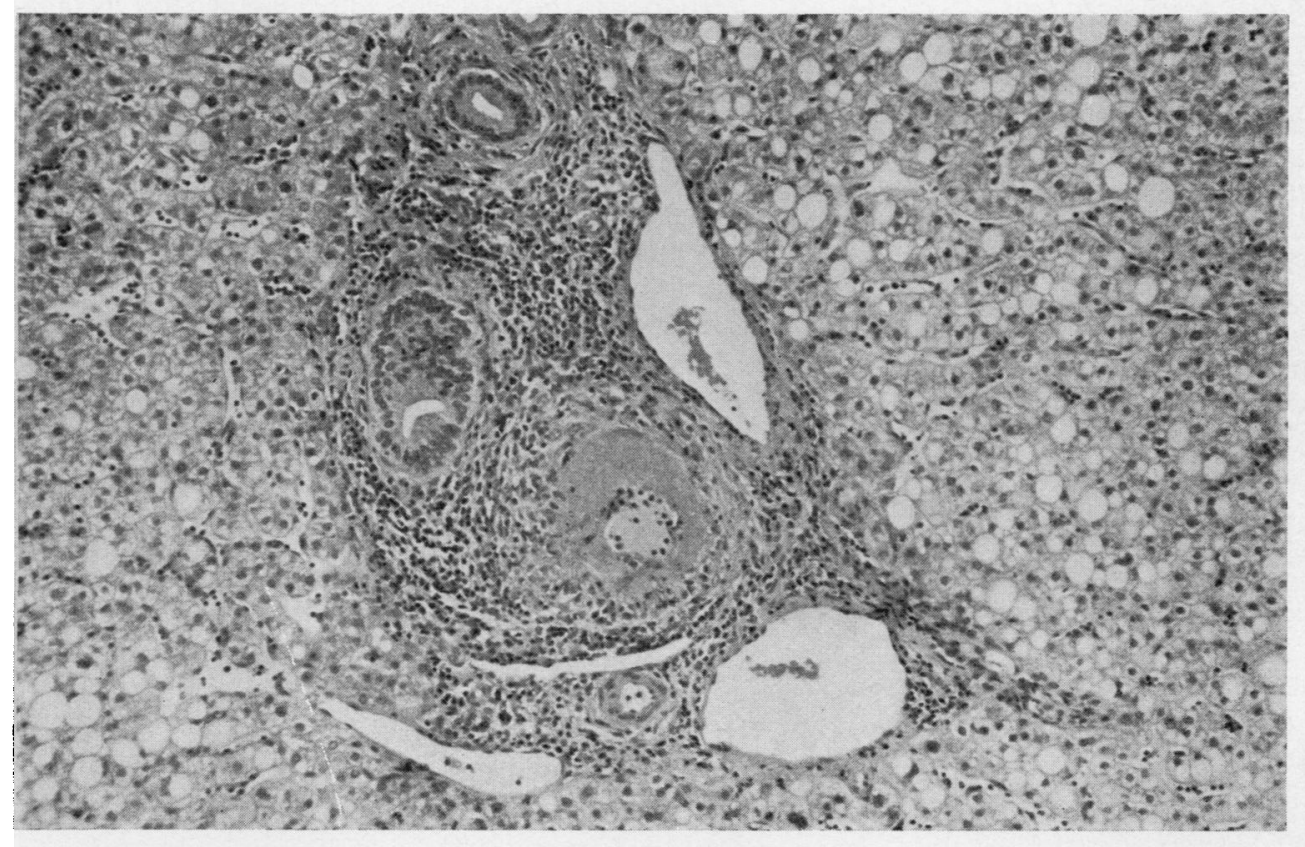

(b)

FIG. 2 Liver biopsy from Case 4, illustrating the active arteritis with round cell infiltration and fibrinoid necrosis in the walls of hepatic vessels. $(a) \times 8 ;(b) \times 33$ 
hepatomegaly in nine and minor nonspecific histological changes in eleven. Liver biopsies were obtained in four of our five patients with systemic lupus erythematosus and two of these showed chronic persistent hepatitis. One biopsy was normal and in the other mild lymphocytic infiltration of the portal tracts occurred. In the latter the changes were similar to those described by MacKay and others (1959) and Dubois (1966) in patients with systemic lupus erythematosus. Although uncommon, chronic active hepatitis has been reported in association with systemic lupus erythematosus (MacKay and others, 1959).

In three patients, hepatic dysfunction was associated with excessive alcohol intake. Only one patient had clinical evidence of gout, although all three patients had hyperuricaemia as well as hypercholesterolaemia. After restriction of alcohol, hepatic function returned to normal, uric acid levels fell to within normal limits, and the serum cholesterol levels were reduced in all three patients. Alcohol-induced hyperuricaemia and hyperlipidaemia has been well documented (Lieber, 1965; Chait, Mancini, February, and Lewis, 1972).

In patients with known liver disease arthralgia is recognized as a not uncommon symptom and has been described in chronic active hepatitis, acute viral hepatitis, and alcoholic cirrhosis (Whelton, 1970). A true arthritis is uncommon, although recently a painless erosive arthritis was described in a patient with chronic active hepatitis (Barnardo, VernonRoberts, and Currey, 1973). Although the arthropathy usually occurs after the liver disease has declared itself, it may precede clinical evidence of liver disease (Whelton, 1970). The four patients who presented with polyarthralgia were all found to have a specific hepatic disorder, the diagnoses including chronic active hepatitis, chronic persistent hepatitis, alcoholic liver disease, and sarcoidosis.

Arthropathy is a common clinical feature of idiopathic haemochromatosis (Schumacher, 1964; Dymock, Hamilton, Laws, and Williams, 1970), but no evidence of this condition was found in the two patients in whom increased iron deposition was shown histologically and the degree of iron deposition did not approach that found in idiopathic haemochromatosis. Both these patients had long-standing rheumatological disorders (seropositive rheumatoid arthritis in one patient and psoriatic arthropathy in the other) and had received prolonged iron therapy.

In several of the patients described in this series, the occurrence of hepatic disease in association with a rheumatological disorder must be fortuitous. Examples include the patients with chronic active hepatitis and primary biliary cirrhosis who had long-standing seropositive rheumatoid arthritis. Such associations may simply reflect the well-known increased susceptibility of patients with one disease associated with abnormalities of immune mechanisms to develop autoimmune disturbances involving other systems.

In conclusion, our results suggest that detailed hepatic investigations, including liver biopsy if indicated, are justified in patients with rheumatic disorders who have hepatomegaly and/or abnormal routine liver function tests. It should not be assumed that these abnormalities are due to liver involvement as part of a multisystem autoimmune disease, as a variety of subclinical liver diseases may be revealed, some of which may be treatable or reversible. In particular, the importance of drug therapy as a cause of hepatic dysfunction in these patients must be emphasized.

\section{Summary}

The results of detailed hepatic investigations are reported in thirty patients who presented to a rheumatology clinic with joint symptoms, and who were found on routine clinical examination or biochemical screening to have hepatomegaly and/or abnormal routine liver function tests. In twenty patients a specific hepatic disorder was found and a varied spectrum of liver disease revealed. The diagnoses included alcoholic liver disease (three patients), drug-induced liver damage (three patients), primary biliary cirrhosis (three patients), chronic persistent hepatitis (three patients), chronic active hepatitis (two patients), polyarteritis nodosa, sarcoidosis, cardiac cirrhosis, and severe fatty change (one patient each).

We wish to thank Dr. J. S. Whittaker who reported the liver histology, and Professor J. M. Evanson for encouragement and advice.

\section{References}

BALl, J. (1954) Ann. rheum. Dis., 13, 277 (Rheumatoid arthritis and polyarteritis nodosa)

Barnardo, D. E., Vernon-Roberts, B., AND CURREY, H. L. F. (1973) Gut, 14, 800 (A case of active chronic hepatitis with painless erosive arthritis)

Blendis, L. M., Ansell, I. D., Jones, K. L., Hamilton, E., and Williams, R. (1970) Brit. med. J., 1, 131 (Liver in Felty's syndrome)

Chait, A., Mancini, M., February, A. W., ANd Lewis, B. (1972) Lancet, 2, 62 (Clinical and metabolic study of alcoholic hyperlipidaemia) 
Cockel, R., Kendall, M. J., Becker, J. F., And Hawkins, C. F. (1971) Ann. rheum. Dis., 30, 166 (Serum biochemical values in rheumatoid disease)

Dubors, E. L. (1966) In 'Lupus Erythematosus', ed. E. L. Dubois, p. 129. McGraw-Hill, New York

Dymock, I. W., Hamilton, E. B. D., Laws, J. W., And Williams, R. (1970) Ann. rheum. Dis., 29, 469 (Arthropathy of haemachromatosis: clinical and radiological analysis of 63 patients with iron overload)

Engleman, E. P., Krupp, M. A., Rinehart, J. F., Jones, R. C., And Gibson, J. R. (1954) J. Amer. med. Ass., 156, 98 (Hepatitis following the ingestion of phenylbutazone)

FENECH, F. F., BANNISTER, W. H., AND GRECH, J. L. (1967) Brit. med. J., 3, 155 (Hepatitis with biliverdinaemia in association with indomethacin therapy)

Gocke, D. J., Hsu, K., Morgan, C., Bombardieri, S., Lockshin, M., and Christian, C. L. (1970) Lancet, 2,1149 (Association between polyarteritis and Australia antigen)

Kelsey, W. M., AND SChARYJ, M. (1967) J. Amer. med. Ass., 199, 586 (Fatal hepatitis probably due to indomethacin)

Kendall, M. J., Cockel, R., Becker, J., And Hawkins, C. F. (1970) Ann. rheum. Dis., 29, 537 (Raised serum alkaline phosphatase in rheumatoid disease: an index of liver dysfunction?)

—, FARr, M., Bold, A. M., AND HaWkins, C. F. (1971) Lancet, 2, 1012 (5-nucleotidase in the serum and synovial fluid of patients with rheumatoid disease)

Kornreich, H., Malouf, N. N., AND Hanson, V. (1971) J. Pediat., 79, 27 (Acute hepatic dysfunction in juvenile rheumatoid arthritis)

Lefkovits, A. M., AND Farrow, I. J. (1955) Ann. rheum. Dis., 14, 162 (The liver in rheumatoid arthritis)

LIEBER, C. S. (1965) Arthr. and Rheum., 8, 786 (Hyperuricemia induced by alcohol)

MACKAY, I. R., TAFT, L. I., AND CowLING, D. C. (1959) Lancet, 1, 65 (Lupoid hepatitis and the hepatic lesions of systemic lupus erythematosus)

Meyler, L., AND HerXheimer, A. (1972) In 'Side Effects of Drugs,' Vol. 7, p. 643. Excerpta Medica, Amsterdam

MovitT, E. R., AND DAVIS, A. E. (1953) Amer.J. med. Sci., 226, 516 (Liver biopsy in rheumatoid arthritis)

Rich, R. R., AND Johnson, J. S. (1973) Arthr. and Rheum., 16, 1 (Salicylate hepatotoxicity in patients with juvenile rheumatoid arthritis)

Russell, A. S., Sturge, R. A., ANd Smith, M. A. (1971) Brit. med. J., 2, 428 (Serum transaminases during salicylate therapy)

Schaller, J., Beckwith, B., AND Wedgwood, R. J. (1970) J. Pediat ., 77, 203 (Hepatic involvement in juvenile rheumatoid arthritis)

Schenker, S., Olson, K. N., DunN, D., Breen, K. J., AND Combes, B. (1973) Gastroenterology, 64, 622 (Intrahepatic cholestasis due to therapy of rheumatoid arthritis)

SCHUMACHER, H. R. (1964) Arthr. and Rheum., 7, 41 (Hemochromatosis and arthritis)

WALKer, J. G., DoniACH, D., AND Doniach, I. (1970) Quart. J. Med., 39, 31 (Mitchondrial antibodies and subclinical liver disease)

Whaley, K., Goudie, R. B., Williamson, J., Nuki, G., Dick, W. C., and Buchanan, W. W. (1970) Lancet, 1, 861 (Liver disease in Sjögren's syndrome and rheumatoid arthritis)

Whelton, M. J. (1970) Brit. J. hosp. Med., 3, 243 (Arthropathy and liver disease) 
, (1962) J. Bone Jt Surg., 44A, 669 (The relationship of ash weight and organic weight of human skeletons)

Van Gerven, D. P., Armelagos, G. J., And Bartley, M. H. (1969) Amer. J. Phys. Anthrop., 31, 23 (Roentgenographic and direct measurement of femoral cortical involution in a prehistoric Mississippian population)

Virtama, P., ANd Helelä, T. (1969) Acta Radiol., Suppl. 293 (Radiographic measurements of cortical bone. Variations in a normal population between 1 and 90 years of age)

VOGT, J. H., AND TøNSAGER, A. (1949) Acta med. scand., 135, 231 (Investigations on the bone chemistry of man II)

WeAVer, J. K., AND Chalmers, J. (1966) J. Bone Jt Surg., 48A, 289 (Cancellous bone: its strength and changes with aging and an evaluation of some methods for measuring its mineral content)

Wils, M. R. (1973) Lancet, 1, 820 (Intestinal absorption of calcium)

Wray, J. B., Sugarman, E. D., AND Schneider, A. J. (1963) J. Amer. Med. Ass., 183, 118 (Bone composition in senile osteoporosis)

Wong, P. C. N. (1966) Clin. Orthop., 45, 55 (Fracture epidemiology in a mixed South-eastern Asian community (Singapore))

Young, M. M., AND Nordin, B. E. C. (1967) Lancet, 2, 118 (Effects of natural and artificial menopause on plasma and urinary calcium and phosphorus)

\section{Correction}

With reference to the paper 'Liver disease in patients with joint symptoms' by Angela M. Hilton, B. E. Boyes, Patricia J. Smith, J. Sharp, and I. W. Dymock, which appeared in the November 1974 edition of Annals of the Rheumatic Diseases (Ann. rheum. Dis., 33, 540); we regret that the figures for this paper were incorrectly placed against their legends. Figure 2a should replace figure 1; figure 1 should replace figure $2 b$; and figure $2 b$ should replace figure $2 a$. 